\title{
The measurement of territorial differences in the information infrastructure in Hungary and the South Transdanubian Region*
}

\begin{abstract}
The information society has become a crucial area of the socio-economic processes over the last two to three decades, yet it was unable to reduce the differences between the development levels of different regions. The developed regions perform better and poorer regions have weaker performance in the development of info-communication technologies. It can be assumed that the lack of the info-communication tools may broaden the divide between the developed and underdeveloped regions. Therefore, it is important to measure and mitigate these differences. The results of such measurements may contribute to the formation of the regional development policy issues.

This paper focuses on the analysis of the factors that play a role in the information society. These factors can help to characterize the information society on both the national and the sub-national level. Our goal is to investigate the territorial inequalities in the information society on a highly disaggregated level since the article studies the relative development of the settlements in the South Transdanubian Region. As a methodological background, we introduce a new and composite index referred to as "the territorial index of information society", which relies on settlement and micro-regional level data collected by the Central Statistical Office of Hungary and other private institutions.

Our results indicate that the best performing settlements are in micro-regions with advantageous positions and that they are the more populated towns or locate within their agglomeration. The less populated settlements in an underdeveloped micro-region have a more disadvantageous position in the information society. Therefore, the information readiness may create differences in a similar way to economic development.
\end{abstract}

Keywords: information society, territorial differences, infrastructure, regional development.

a) Hungarian Academy of Sciences Centre for Economic and Regional Studies Institute for Regional Studies, H-7621 Pécs Pécs, Papnövelde utca 22., Hungary. E-mail: pagerb@rkk.hu

b) Hungarian Academy of Sciences Centre for Economic and Regional Studies Institute for Regional Studies, H-7621 Pécs Pécs, Papnövelde utca 22., Hungary. E-mail: zsibok@rkk.hu

* This study has been prepared in the frame of TÁMOP-4.2.2.C-11/1/KONV-2012-0005 "Jól-lét az információs társadalomban" (Well-being in the information society) project. 


\section{Introduction}

The information and info-communication technologies have a central role in the socioeconomic processes of the last two to three decades through the permanently developing technology and faster communication opportunities. The growing scale of the information and technological innovations has increasingly determined the social and economic environment. The accelerated communication between organizations and individuals has led to an increased volume and more rapid exchange of information (Lengyel 2010). The diffusion of information has opened new opportunities in the business and economic processes, as well as in social life and communication (for example, social media). Information has added to the economic processes, and has become a crucial factor. Thus, the phenomenon of information society has become an important research question for social sciences scholars in recent decades. This research, which is a part of a broad scientific project at the University of Pécs, intends to capture the territorial differences of the information society. Additionally, the project attempts to give some suggestions for development policy based on the information society analysis. The theoretical findings regarding the information society have been already summarized, and an indicator system that may help to determine these differences will be created. The first results of the indicator system are interpreted in this paper.

First, it should be briefly clarified as to what "information society" precisely means. There have been many attempts in the literature to determine "information society", generating much debate. Farkas (2001), Z. Karvalics (2005) and also Ropolyi (2006) attempted to clarify what does mean the "information society", because this expression was also used for determining various conceptions (like knowledge-based society). The information society has six different aspects: technology, occupational change, economy, space (spatial dimension), social and cultural (Webster 1995). According to Masuda, one of the first scholars dealing with this concept, information society is such kind of society that has been built on the exploitation of information resources, and this kind of society progressively replaces the model of industrial and mass-production society. The information society also possesses a high-level intellectual creativity (Masuda 1980, Szépvölgyi 2008). Farkas (2002) has stressed the handling and application of information in his approach. The definition of OECD also underlines that many employees deal with handling, production and distribution of information in the information society (OECD, 1996). The infrastructural aspect can be observed, for example, in the description of the information society by Fodor $(2000)^{1}$ or Erdősi (2002). They have emphasized that a new lifestyle and, the accelerated stream of information have been realized through the technological development and innovations in info-communication technologies. Ropolyi (2006) claims that regular use of information technologies (especially the internet) has created a new organizing form of community. However, it is not worth to term this organizing form as society, but it may be designated as "network entity". According to Z. Karvalics (2005), the real dimensions of information society should not be looked for

\footnotetext{
${ }^{1}$ The approach of Fodor (2000) is accepted by most of those Hungarian researchers who deal with socio-economic aspects of information society (Jakobi 2007).
} 
only in telecommunication or computerization, but might be found through education, science, innovation, content and culture. Therefore, information society is a complex phenomenon that includes many factors (Karvalics 2005). Approaches like "knowledge society" or "post-industrialist society" relate more or less to the information society (Jakobi 2007). The networks and the use of technologies play an important role in territorial inequalities of information society. The lack of adequate infrastructure may exclude the underdeveloped territories from the stream of information and knowledge, which may result in significant differences between the centre and peripheries. Graham (2000) provided some examples on how the development of information and communication technology (ICT) extends the digital divide among different regions or cities within a country. He claims that a close connection can be observed between ICTs, global urban polarization, and the extending power of transnational corporations. Thus, it "can compromise and erode the social, economic and cultural powers of those groups and spaces that are rendered off-line or marginal" (Graham 2000, p. 27.). Similar observations have been made by van der Meer and his colleagues (2003) about the territorial differences in the ICT sector.

The territorial analyses of the information society are determined by the approach that researchers use (Jakobi 2007). The information society is characterized by many indexes, which measure the info-communication technologies, attitudes or infrastructure globally. These indexes have been created by different organizations like the International Telecommunication Union (ITU). There are indexes that indicate the available infrastructure (for example, networks, phone lines, tools) and where people use this infrastructure (at home, public places or the workplace). The so-called readiness indexes (like E-readiness index) measure the preparedness of individuals and society (Vajkai 2008). There are indicator systems that focus on the digital literacy. Other indicators measure the attitudes that characterize the use of the ICT tools. One of the most common indexes in use, to measure the information society, is the ICT Development Index (IDT). This indicator captures three sub-indexes: the Access sub-index (ICT readiness infrastructure, access), the Use sub-index (intensity) and the Skills sub-index (ICT capabilities). Thus, the ICT Development Index characterizes the dimensions of information society in the countries of the world. The IDT has been computed for 157 countries in the 2013 edition (ITU 2013).

Several measurements about the information society have already been carried out by Hungarian academics in recent years. Rechnitzer $(1990,1993)$ already investigated the territorial system of innovation at the beginning of the 1990s. This study was repeated some years later in order to observe the changes since the former investigation (LengyelRechnitzer 2000). Bakonyi and Bálint (1996) investigated the research and development networks (knowledge bases and education), which were named as the first step in the innovation chain after invention (Bakonyi-Bálint 1996). Nagy and his colleagues analysed statistical data, guidelines, national and regional strategies concerning the information society. The county level dispersion of the domain names have also been involved in the analysis (Kanalas-Nagy 2002). Some studies have investigated the existence of info-communication infrastructure and institutions, and their role in configuration of the urban system in Hungary (Döry-Ponácz 2003, Rechnitzer-GroszCsizmadia 2003). Jakobi (2007) has analysed the national competitiveness of information 
society and the regional footprint of information society in Hungary. Szépvölgyi (2008) composed an indicator system that characterized the information attributes of Hungarian micro-regions. A recent analysis of the territorial differences of a Hungarian social network website (iWiW) has carried out by Lengyel and Jakobi (2014). This paper is a good example for the use of new types of data to characterize the territorial differences in the information society.

This research analyses either general measurement regarding the performance of information society of Hungarian territories or special processes regarding the use of information society or the attitudes of people. Therefore, the applied indicators have depended on the type of measurement. This research focuses on the infrastructural approach of the information society, as infrastructure is mostly measured by statistical data, which is readily available for households. We have two goals:

- determining the territorial disparities of information society within the South

Transdanubian Region;

- creating an index that involves the statistical measured factors regarding information society, and analysing the "information readiness" of South Transdanubian settlements.

In the next section, the territorial disparities of information society in the South Transdanubian Region are presented. The methodology of the created index is introduced in the third section. Following this, the results and main findings of the index are explained prior to drawing the conclusions.

\section{Territorial differences of information infrastructure in the South Transdanubian region}

The information society in the South Transdanubian Region was chosen for two reasons. One is that it corresponds to the framework of the large-scale research project conducted by the University of Pécs. Secondly, similar surveys at a disaggregated territorial level have been made in other regions of Hungary, but, to date, are lacking in the South Transdanubian region.

The Hungarian Central Statistical Office and a private research institution (eNET Internet Research and Consulting Ltd.) collect data in relation to information society on the micro-regional or settlement level, which can be accessed through TEIR (Hungarian Settlement Information System). These data are "hard" data, since they are related to the technological aspects of information society. Although they may be useful to provide insight into some important, infrastructure related territorial characteristics of information society, ideally, a database would also contain "soft" data. At this time, it is not possible to overcome these limitations, since, for example, survey data or more detailed information about internet service providers and local market environment, as well as the use of information technology, are not available at the micro-regional or settlement level.

Concerning the South Transdanubian region, the following data was analysed on settlement and micro-regional level (Table 1): 
Information technology indicators used in the analysis

\begin{tabular}{|c|c|c|c|}
\hline Indicator & Territorial level & Period & Source \\
\hline $\begin{array}{l}\text { Number of telephone lines including ISDN lines } \\
\text { of which: } \\
\text { - } \text { number of ISDN lines } \\
\text { - } \text { number of individual telephone lines } \\
\text { - number of service telephone lines } \\
\text { - number of business telephone lines }\end{array}$ & settlement & 2004 to 2012 & $\mathrm{CSO}$ \\
\hline Number of cable television subscribers & settlement & 2001 to 2011 & $\mathrm{CSO}$ \\
\hline Number of houses subscribing cable television & settlement & 2001 to 2012 & $\mathrm{CSO}$ \\
\hline $\begin{array}{l}\text { Number of people having at least } 30 \mathrm{Mbps} \\
\text { internet access }\end{array}$ & settlement & 2010 to 2013 & eNET \\
\hline $\begin{array}{l}\text { The level of electronic government client service } \\
0 \text { - no website } \\
1 \text { - information } \\
2 \text { - interaction } \\
3 \text { - bilateral interaction } \\
4 \text { - transaction }\end{array}$ & settlement & 2003 to 2010 & eNET \\
\hline Number of internet subscriptions & settlement & 2003 to 2010 & eNET \\
\hline Number of internet users & micro-region & 2003 to 2010 & eNET \\
\hline $\begin{array}{l}\text { Number of mobile phone subscriptions } \\
\text { per } 1000 \text { people }\end{array}$ & micro-region & 2003 to 2010 & eNET \\
\hline Number of PCs per 1000 people & micro-region & 2003 to 2010 & eNET \\
\hline
\end{tabular}

Source: authors' elaboration.

As the fourth column of Table 1 indicates, the availability of the data is quite variable for the different time periods. Hence, the possibility of analysing the dynamics of the data is limited - it would enrich the research, however, currently, this is not the primary aim. For this reason, the study covered the most recent period for which the maximum data are available.

In certain cases, it is reasonable to compute and analyse (instead of the raw numbers) the number of telephone (ISDN) lines per 1000 people, or the ratio of houses subscribing to the telephone, internet or cable television in order to get an insight into the relative development of a settlement. The data covering ISDN lines may draw a somewhat distorted picture about the development of information infrastructure since ISDN technology is becoming outdated.

From the data, we generally see that in terms of the information society development measures, the settlements of Baranya and Somogy County are below the national level, while the settlements in Tolna County are above that (Table 2). 
Main indicators of information society in the South Transdanubian region, 2012

\begin{tabular}{l|c|c|c|c|c|c|c}
\hline \multicolumn{1}{|c|}{ County } & $\begin{array}{c}\text { Number of } \\
\text { telephone } \\
\text { lines } \\
\text { (including } \\
\text { ISDN lines) } \\
\text { per 1000 } \\
\text { people }\end{array}$ & $\begin{array}{c}\text { Ratio of } \\
\text { telephone } \\
\text { lines } \\
\text { including } \\
\text { ISDN lines } \\
\text { to the } \\
\text { number of } \\
\text { houses, } \%\end{array}$ & $\begin{array}{c}\text { Number of } \\
\text { ISDN lines } \\
\text { per } 1000 \\
\text { people }\end{array}$ & $\begin{array}{c}\text { Ratio of } \\
\text { ISD lines } \\
\text { to the } \\
\text { number of } \\
\text { houses, \% }\end{array}$ & $\begin{array}{c}\text { Ratio of } \\
\text { houses } \\
\text { connecting } \\
\text { to cable } \\
\text { television } \\
\text { network, \% }\end{array}$ & $\begin{array}{c}\text { Ratio of } \\
\text { houses } \\
\text { having at } \\
\text { least } \\
30 \text { Mbps } \\
\text { internet } \\
\text { access, \% }\end{array}$ & $\begin{array}{c}\text { Ratio of } \\
\text { internet sub- } \\
\text { scriptions to } \\
\text { the number } \\
\text { of houses, } \\
2010, \%\end{array}$ \\
\hline Baranya & 197.09 & 45.39 & 11.22 & 2.69 & 22.42 & 6.69 & 73.43 \\
Somogy & 192.90 & 40.74 & 11.60 & 2.48 & 23.06 & 9.21 & 60.59 \\
Tolna & 272.65 & 61.10 & 15.11 & 3.44 & 55.13 & 30.45 & 58.28 \\
\hline National average & 214.95 & 47.50 & 12.46 & 2.89 & 28.02 & 11.59 & 66.11
\end{tabular}

Source: authors' elaboration based on TEIR data.

There are marked differences in the indicator values in terms of the size (or status) of the settlements. As expected, all the indicators are the highest in the three county seats, while the lowest values are in the villages. In general, information society is more developed in larger settlements. Perhaps, this is one of the reasons behind the high relative development of the settlements in Tolna County - since the average size of the towns and villages is larger than that in Baranya and Somogy County.

Around half of the settlements (which are all villages) are regarded as backward from social, economic and infrastructural points of view ${ }^{2}$ in the South Transdanubian region (143 of 341 settlements in Baranya County, 122 of 245 in Somogy County and 50 of 109 in Tolna County). This kind of backwardness is also reflected by the values of the main information society development indicators (Table 3). For example, the ratio of houses having a telephone line subscription is 54.4 in the more developed settlements and only 37.5 in the backward ones. Concerning cable television access, these ratios are 17.4 (backward villages) and 37.9 (developed settlements). Broadband (at least $30 \mathrm{Mbps}$ ) internet access is even more scarce in the backward settlements ( 8.3 per cent of the houses compared to 14.6 percent in the developed settlements). Furthermore, 72.9 percent of houses have internet subscription in the more developed settlements contrasting with only 58.8 percent of houses in the backward villages.

In Baranya, there are no cable television subscriptions in 119 settlements and no broadband internet connections in 233 settlements (out of 301 settlements). The corresponding figures are 88 and 177 in Somogy County (out of 245 settlements), and only 1 and 10 (out of 109 settlements) in Tolna County, respectively. 
Some important indicators of information society with regard

to the backwardness of settlements, 2012

\begin{tabular}{|c|c|c|c|c|c|c|c|c|}
\hline \multirow[t]{2}{*}{ County } & \multicolumn{2}{|c|}{$\begin{array}{c}\text { Ratio of telephone } \\
\text { lines (including ISDN } \\
\text { lines) to the number of } \\
\text { houses }\end{array}$} & \multicolumn{2}{|c|}{$\begin{array}{c}\text { Number of houses } \\
\text { having access to cable } \\
\text { television }\end{array}$} & \multicolumn{2}{|c|}{$\begin{array}{c}\text { Ratio of people having } \\
\text { at least } 30 \mathrm{Mbps} \\
\text { internet access }\end{array}$} & \multicolumn{2}{|c|}{$\begin{array}{l}\text { Ratio of internet } \\
\text { subscriptions to the } \\
\text { number of houses, } \\
2010\end{array}$} \\
\hline & $\begin{array}{c}\text { not } \\
\text { backward }\end{array}$ & backward & $\begin{array}{c}\text { not } \\
\text { backward }\end{array}$ & backward & $\begin{array}{c}\text { not } \\
\text { backward }\end{array}$ & backward & $\begin{array}{c}\text { not } \\
\text { backward }\end{array}$ & backward \\
\hline Baranya & 53.81 & 36.08 & 31.16 & 12.77 & 8.24 & 4.98 & 78.73 & 67.57 \\
\hline Somogy & 48.28 & 33.14 & 34.34 & 11.68 & 13.72 & 4.67 & 67.11 & 54.02 \\
\hline Tolna & 68.64 & 52.21 & 63.87 & 44.81 & 33.64 & 26.69 & 69.43 & 45.11 \\
\hline National average & 53.01 & 36.46 & 33.70 & 16.64 & 9.34 & 4.86 & 75.31 & 53.17 \\
\hline
\end{tabular}

Source: authors' elaboration based on TEIR data.

Some additional indicators are measured at the micro-regional level, which may also give some insight into the features of information society of the South Transdanubian region (Table 4 and Table 5). In contrast to the above data, these measures are quite similar across the three counties of the region (partly, due to the higher level of aggregation). However, in terms of relative development (disadvantageous situation) ${ }^{3}$, the indicators differ across the micro-regions.

Table 4

Some important micro-regional level indicators of information society in the South Transdanubian region, 2010

\begin{tabular}{l|c|c|c}
\hline \multicolumn{1}{c|}{ County } & $\begin{array}{c}\text { Mobile subscriptions } \\
\text { per 1000 people }\end{array}$ & $\begin{array}{c}\text { Provision of PCs } \\
\text { per 1000 people }\end{array}$ & $\begin{array}{c}\text { Percent of internet } \\
\text { users, } \%\end{array}$ \\
\hline Baranya & 1005.7 & 462.1 & 33.28 \\
Somogy & 1009.9 & 464.7 & 32.47 \\
Tolna & 1035.8 & 470.1 & 33.21 \\
\hline National average & 1059.5 & 469.3 & 34.32
\end{tabular}

Source: authors' elaboration based on TEIR data. 
Some important indicators of micro-region level information society with regard to the disadvantaged situation of the settlements, 2010

\begin{tabular}{l|c|c|c|c|c|c}
\hline \multirow{2}{*}{ County } & \multicolumn{5}{|c|}{ Backwardness $^{\text {a) }}$} & \multirow{2}{*}{ Average } \\
\cline { 2 - 6 } & NHH & ÁTM & HH & LHH & LHHK & \\
\hline
\end{tabular}

Provision of PCs per 1000 people

\begin{tabular}{l|r|r|r|r|r|r} 
Baranya & 524.0 & & 454.0 & & 451.3 & 462.1 \\
Somogy & 457.0 & 453.1 & 479.7 & 452.0 & 452.0 & 464.7 \\
Tolna & 483.2 & & 456.0 & & 452.0 & 470.1 \\
\hline National average & 492.0 & 452.7 & 458.0 & 460.4 & 452.1 & 469.3 \\
\end{tabular}

\begin{tabular}{l|l|l|r|r|r|r} 
Baranya & 1224.0 & & 985.7 & & 955.3 & 1005.7 \\
Somogy & 1158.0 & 987.1 & 1057.2 & 961.0 & 945.4 & 1009.9 \\
Tolna & 1092.3 & & 990.0 & & 951.0 & 1035.8 \\
\hline National average & 1186.3 & 1079.5 & 1000.9 & 942.3 & 941.4 & 1059.5 \\
\multicolumn{7}{|c}{ Percent of internet users, \% }
\end{tabular}

\begin{tabular}{l|l|l|l|l|l|l} 
Baranya & 45.19 & & 30.33 & & 33.19 & 33.28 \\
Somogy & 34.04 & 29.84 & 34.24 & 34.55 & 29.90 & 32.47 \\
Tolna & 38.01 & & 29.46 & & 25.93 & 33.21 \\
\hline National average & 40.08 & 34.76 & 31.60 & 29.63 & 29.00 & 34.32
\end{tabular}

Source: authors' elaboration based on TEIR data

a) Legend: NHH - micro-regions not in a disadvantageous position, ÁTM - transitionally supported micro-region, HH micro-region in a disadvantageous position, LHHK - micro-region in the most disadvantageous position

The micro-region of the county seat of Somogy County (Kaposvár micro-region) is regarded as disadvantageous $(\mathrm{HH})$. Due to this, the values of the information society indicators are reasonably good in this category. Otherwise, the indicators reflect the backwardness of the micro-regions relatively well.

Telehouses and eHungary Points, ${ }^{4}$ as public internet access points, are important parts of information society in remote settlements where information infrastructure is underdeveloped (Table 6 and 7).

\footnotetext{
${ }^{4}$ A part of the telehouses are regarded as eHungary Points in the settlements.
} 
Number of eHungary Points and Telehouses in the counties of Hungary, 2014

\begin{tabular}{l|c|c|c}
\hline \multicolumn{1}{c|}{ County } & $\begin{array}{c}\text { Number of } \\
\text { settlements }\end{array}$ & $\begin{array}{c}\text { Number of eHungary } \\
\text { Points }\end{array}$ & $\begin{array}{c}\text { Number of } \\
\text { Telehouses }\end{array}$ \\
\hline Bács-Kiskun & 119 & 71 & 11 \\
Baranya & 301 & 78 & 34 \\
Békés & 75 & 73 & 15 \\
Borsod-Abaúj-Zemplén & 358 & 98 & 28 \\
Budapest & 1 & 21 & 9 \\
Csongrád & 60 & 72 & 30 \\
Fejér & 108 & 43 & 13 \\
Györ-Moson-Sopron & 183 & 55 & 15 \\
Hajdú-Bihar & 82 & 57 & 26 \\
Heves & 121 & 60 & 6 \\
Jász-Nagykun-Szolnok & 78 & 38 & 9 \\
Komárom-Esztergom & 76 & 25 & 8 \\
Nógrád & 131 & 44 & 28 \\
Pest & 187 & 52 & 18 \\
Somogy & 245 & 72 & 25 \\
Szabolcs-Szatmár-Bereg & 229 & 113 & 19 \\
Tolna & 109 & 54 & 11 \\
Vas & 216 & 59 & 13 \\
Veszprém & 217 & 61 & 33 \\
Zala & 258 & 80 & 359 \\
\hline
\end{tabular}

Source: authors' elaboration based on KSH and State Secretary for Infocommunications data.

According to the most recent data (June 2014), there are 78 eHungary Points and 34 telehouses in Baranya County. Altogether, 78 settlements are provided with these facilities, which are lacking in the remaining 223 settlements. In Somogy County, there are 72 eHungary Points and 18 telehouses. These services are available in 69 settlements, while in 176 of the settlements, they are not accessible. Tolna County has 54 eHungary Points and 19 telehouses. These services are present in 53 settlements, and absent in 56 others. In Pécs, the most developed city and the county seat of Baranya, there are nine eHungary Points (of which one is a telehouse). There are only two in Szekszárd, and no eHungary Points are available in Kaposvár.

eHungary Points and Telehouses with regard to the settlement status, 2014

\begin{tabular}{|c|c|c|c|c|c|}
\hline County/Status & Village & Large village & Town & County seat & Total \\
\hline \multicolumn{6}{|c|}{ Number of settlements provided with eHungary Points or Telehouses } \\
\hline Baranya & 66 & 2 & 9 & 1 & 78 \\
\hline Somogy & 58 & 0 & 11 & 0 & 69 \\
\hline Tolna & 39 & 4 & 9 & 1 & 53 \\
\hline Total & 163 & 6 & 29 & 2 & 200 \\
\hline \multicolumn{6}{|c|}{ Number of settlements without eHungary Points or Telehouses } \\
\hline Baranya & 218 & 1 & 4 & 0 & 223 \\
\hline Somogy & 169 & 2 & 4 & 1 & 176 \\
\hline Tolna & 54 & 1 & 1 & 0 & 56 \\
\hline Total & 441 & 4 & 9 & 1 & 455 \\
\hline
\end{tabular}

Source: State Secretary for Infocommunications. 
The data indicate that more than 84 percent of the settlements that are provided with eHungary Points or Telehouses are villages (or large villages), and around 15 percent of them are towns or cities. From the 200 settlements that are provided with eHungary Points or Telehouses, 59 are located in a most disadvantaged micro-region (21 settlements in Baranya, 22 in Somogy and 16 in Tolna County), 88 are located in a disadvantaged micro-region (48 settlements in Baranya, 36 in Somogy and 4 in Tolna County), and 53 can be found in micro-regions not (or temporarily) considered as disadvantaged (9 settlements in Baranya, 11 in Somogy and 33 in Tolna County).

\section{The methodology of the "territorial index of information society"}

This paper introduces a new and composite index for measuring territorial disparities of information society. A similar index has already been used for determining the differences among European regions regarding information society. The statistical variables that were introduced in the second section have been used. They can be divided into two groups: the settlement level indicators and the micro-regional level data. Altogether eight indicators were used at first (five on the settlement level and three on the micro-region level), and five leading indicators were created by transformation and aggregation of the original indicator (Table 8).

Table 8

Indicators for measuring territorial differences of information society

\begin{tabular}{|c|c|c|}
\hline Indicators & Main indicators & Territorial level \\
\hline Number of private phone lines & \multirow{2}{*}{$\begin{array}{l}\text { The rate of the number private and } \\
\text { ISDN phone lines in the flats } \\
\text { (houses) of the settlement }\end{array}$} & settlement \\
\hline Number of ISDN lines & & settlement \\
\hline Number of cable TV subscriptions & $\begin{array}{l}\text { The rate of cable TV subscriptions } \\
\text { in the flats (houses) of the } \\
\text { settlement }\end{array}$ & settlement \\
\hline Number of internet subscriptions & $\begin{array}{l}\text { The rate of internet subscriptions in } \\
\text { the flats (houses) of the settlement }\end{array}$ & settlement \\
\hline Number of internet users & \multirow{3}{*}{$\begin{array}{l}\text { Micro-regional indicator - } \\
\text { multiplication of the three original } \\
\text { indicators }\end{array}$} & micro-region \\
\hline $\begin{array}{l}\text { Number of mobile phone } \\
\text { subscriptions per } 1000 \text { capita }\end{array}$ & & micro-region \\
\hline Number of PCs per 1000 capita & & micro-region \\
\hline E-administration level & Quantified version of this indicator & settlement \\
\hline
\end{tabular}

Source: authors' elaboration.

The number of flats (houses) was used for computing rates, based on the assumption that there is generally one subscribed phone line, cable TV and/or internet connection per household, and this connection may be used by other family members. The e-administration level is a qualitative measure, which indicates this level at settlement level. It represents the "e-readiness" of a municipality. As data was available for 2005 to 2012, the analysis was also applied to each year. 
After creating the main indicators, ${ }^{5}$ the descriptive and correlation statistics were checked. Extraordinary attention was paid to the skewness values because the lack of normal distribution might mar the final values. If the skewness of an indicator has fallen out of the $[-1 ; 1]$ range, then it should be transformed. We have used Box-Cox transformation for transforming these values (1).

$$
y_{1}=\left\{\begin{array}{l}
\text { If } \lambda \neq 0 \text {, then } \phi\left(y_{1}\right)=\frac{y_{1}^{\lambda}-1}{\lambda} \\
\text { If } \lambda=0 \text {, then } \phi\left(y_{1}\right)=\ln \left(y_{1}\right)
\end{array}\right\}
$$

The application of this method was as per the EU Regional Competitiveness Index (Annoni-Kozovska, 2010) and the REDI Index (Regional Entrepreneurship and Development Index) (Szerb et al., 2014). According to these, $\lambda=2$, if skewness is negative, left-handed $(\mathrm{K}<-1)$ and $\lambda=(-0.05)$, if skewness is positive, right-handed $(\mathrm{K}>1)$. The indicators of phone lines, cable TV and internet subscriptions should not be transformed, while the micro-regional indicator was transformed in almost every year. The next step was the normalization of the pillars. The min-max normalization technique was applied. The original min-max technique computes the indicator values to a scale from 0 to 1 . This technique was applied but on a scale from 0 to 100 (2). Therefore, the maximum value of each indicator in each year was 100 .

$$
z_{i}=\frac{x_{i}}{\max \left(x_{i}\right)} * 100
$$

After normalization, the territorial index of information society was computed by averaging the four main indicators for each settlement of the South Transdanubian region. Index values for every year were available; hence an average value was computed for the analysed period. The e-administration of the settlements was also represented. The qualitative indicator had five levels, which depended on the level of interaction between the municipality and users through the website of the settlement: 0 - no website, 1 - information, 2 - interaction, 3 - bilateral interaction, 4 - transaction. In order to use this indicator, new values ${ }^{6}$ were calculated for the different levels, and the index score was multiplied by this new indicator value.

A sensitivity analysis was conducted on the new index, as well. Weights were applied to the calculation of the main index values. Thus, the four main indicators received different weights: phone lines $-20 \%$, cable television subscription $-30 \%$, internet subscription $-40 \%$ and the micro-regional indicator $-10 \%$. The qualitative indicator of e-administration was not weighted, it was multiplied by the index value in the same way. The main index values were calculated again, and the difference between the normal average and weighted average computed index values were analysed by Spearman's rank correlation coefficient. The coefficient values represented a very strong relationship (average $\rho=0.952)^{7}$ in the examined years. The index was analysed in a different way; a main indicator was randomly eliminated in each year, and the index values calculated in

\footnotetext{
${ }^{5}$ We checked the descriptive statistics of the original, and created indicator in the case of micro-regional indicator. If the original values should be transformed because of the excessive skewness, we computed further with the transformed version of the indicators. For the detailed description of transformed indicators see Appendix 1

${ }^{6}$ Level $0=1.00$, level $1=1.01$, level $2=1.02$, level $3=1.03$ and level $4=1.04$

${ }^{7}$ The $\rho$ values spread between 0.949 and 0.967 in the examined years except 2005 when it was 0.926 .
} 
this way. The Spearman's coefficient values were also relatively strong (average $\rho=0.9$ ) in this case, although, it was slightly weaker than in the other analysis ${ }^{8}$. According to these results, the index is relatively robust and the shift or elimination of indicators did not cause significant changes in the ranking.

\section{The results of the index}

Altogether, 655 settlements from the three counties of the region were analysed. The ranking of settlements was investigated to try to find a connection between the index values, the status of the settlement and the development stage of the micro-region. It can be observed that the best performing settlements are towns or those villages that are located in the agglomeration of a more populated town (like Dunaszentgyörgy or Györköny in the neighbourhood of Paks) or a county seat (like Keszü, Pogány or Pellérd in the neighborhood of Pécs). All three county seats are among the ten best performing settlements (Table 9).

Table 9

The ten best and worst performing settlements in the region

\begin{tabular}{|c|c|c|c|c|}
\hline Settlement & County & Micro-region & $\begin{array}{l}\text { Development } \\
\text { stage of the } \\
\text { micro-region }\end{array}$ & Index value \\
\hline Paks & Tolna & Paksi & $\mathrm{NHH}$ & 78.47 \\
\hline Keszü & Baranya & Pécsi & $\mathrm{NHH}$ & 68.53 \\
\hline Szekszárd & Tolna & Szekszárdi & $\mathrm{NHH}$ & 68.22 \\
\hline Pogány & Baranya & Pécsi & $\mathrm{NHH}$ & 66.61 \\
\hline Dunaszentgyörgy & Tolna & Paksi & $\mathrm{NHH}$ & 65.94 \\
\hline Pellérd & Baranya & Pécsi & $\mathrm{NHH}$ & 65.64 \\
\hline Orfü & Baranya & Pécsi & $\mathrm{NHH}$ & 65.59 \\
\hline Pécs & Baranya & Pécsi & $\mathrm{NHH}$ & 65.29 \\
\hline Györköny & Tolna & Paksi & $\mathrm{NHH}$ & 62.76 \\
\hline Kozármisleny & Baranya & Pécsi & $\mathrm{NHH}$ & 62.65 \\
\hline$\cdots$ & & & & \\
\hline$\cdots$ & & & & \\
\hline $\begin{array}{l}\cdots \\
\text { Hencse }\end{array}$ & Somogy & Kadarkúti & LHHK & 13.85 \\
\hline Old & Baranya & Siklósi & $\mathrm{HH}$ & 13.70 \\
\hline Hedrehely & Somogy & Kadarkúti & LHHK & 13.24 \\
\hline Siklósnagyfalu & Baranya & Siklósi & $\mathrm{HH}$ & 12.74 \\
\hline Rinyabesenyő & Somogy & Nagyatádi & $\mathrm{HH}$ & 11.39 \\
\hline Kisasszond & Somogy & Kadarkúti & LHHK & 11.07 \\
\hline Alsószentmárton & Baranya & Siklósi & HH & 8.25 \\
\hline Visnye & Somogy & Kadarkúti & LHHK & 7.28 \\
\hline Kökút & Somogy & Kadarkúti & LHHK & 6.56 \\
\hline Pálmajor & Somogy & Kadarkúti & LHHK & 4.97 \\
\hline
\end{tabular}

Legend: $\mathrm{NHH}$ - micro-region not in disadvantageous position, $\mathrm{HH}$ - micro-region in disadvantageous position, LHHK micro-region in the most disadvantageous position

Source: authors' computation and elaboration

\footnotetext{
${ }^{8}$ For detailed values see Appendix 2.
} 
Paks is the best performing settlement from the aspect of information society and information infrastructure over the investigated period. All settlements among the best 10 locate in micro-regions not in a disadvantageous position. Two of the three County seats (Pécs and Szekszárd) are among the ten best settlements. Contrarily, most of the ten worst performing settlements are small villages. Only one settlement among the ten most underdeveloped has a population greater than 1000 people; in the other villages, live only a few hundreds of people. These settlements are located in micro-regions with a disadvantageous position. It can be observed that the economic situation of a microregion may influence the performance of information society, as well.

The relationship between the index and the measured development stage for microregions was analysed. On checking the strength of this relationship by Spearman rank correlation, there is significant, but relatively weak relationship $(\rho=0.22)$ among these factors. The settlements were then grouped according the development stage of the micro-regions, creating five groups (NHH, HH, ÁTM, LHH and LHHK - for the meaning of acronyms, see in the legend of the table) (Table 10).

Table 10

Main results of the development stage analysis

\begin{tabular}{l|r|r|r|r|r}
\hline \multicolumn{1}{c|}{ Denomination } & \multicolumn{1}{c|}{ NHH } & HH & ÁTM & LHH & LHHK \\
\hline Average index value & 50.74 & 33.96 & 30.96 & 29.68 & 27.82 \\
Range & 50.3 & 53.99 & 25.77 & 26.93 & 46.53 \\
Maximum value & 78.47 & 62.24 & 48.94 & 49.32 & 51.5 \\
Minimum value & 28.17 & 8.25 & 23.17 & 22.39 & 4.97 \\
Number of towns & 11 & 13 & 4 & 1 & 12 \\
Number of villages & 99 & 267 & 20 & 23 & 205 \\
Proportion of regional & & & & 1.4 & 17.4 \\
$\quad$ population, \% & 40.9 & 36.7 & 3.6 & & 152
\end{tabular}

Legend: NHH - micro-regions not in a disadvantageous position, ÁTM - transitionally supported micro-region, $\mathrm{HH}$ - micro-region in a disadvantageous position, $\mathrm{LHH}$ - micro-region in the most disadvantageous position, LHHK - microregion in the most disadvantageous and complex position

Source: authors' computation and elaboration

It can be observed that the average index value correlates with the development stage; hence those micro-regions that are not in a disadvantageous position have higher scores on average than the supported micro-regions. However, the relatively high difference between the maximum and minimum values refers to the relatively high dispersion of the scores within the different groups (especially in $\mathrm{NHH}, \mathrm{HH}$ and LHHK). Therefore, it may prove the relatively weak result of Spearman rank correlation analysis in the development stage and the index values.

The NHH group has the highest average values index value. It has the highest proportion (almost 41\%) from the regional population, involving five micro-regions, some of the bigger towns and mostly those villages located in the agglomeration of these towns. The above average performing micro-regions are Paks, Szekszárd and Pécs microregions, while the lowest performance includes the Siófok micro-region. Its score lags 10 points behind the group average. The HH group includes slightly more than one-third 
of the whole regional population (36.7\%). According to the average index values, this group has the second highest scores but it significantly lags behind the score of the $\mathrm{NHH}$ group. It comprises altogether nine micro-regions. The biggest town of this group is Kaposvár, which micro-region has the highest score in this group. Relatively good performances include Mohács and Dombóvár micro-regions, but the peripheral microregions (like Nagyatád, Siklós or Marcali) perform below the group average. There are two smaller groups according the development stage: ÁTM and LHH groups, which include altogether three micro-regions (Balatonföldvár, Fonyód and Tab) and 48 settlements. These groups represent similar values in the index values. The most underdeveloped micro-regions (LHHK) have the worst scores. However, it should be noted that the high range of the index values within the group represent a high heterogeneity concerning the information infrastructure. The better performing microregions within this group are Barcs and Sellye micro-regions, while half of the eight micro-regions are around the average. The worst scores are the Lengyeltóti and Kadarkút micro-regions, which lag significantly behind the group average.

\section{Conclusion}

The study had two goals: determining the territorial disparities of information society within the South Transdanubian region and creating an index to help analyse the "information readiness" of South Transdanubian settlements.

The data indicates that, just like in other areas of socio-economic development, the settlements of the South Transdanubian Region are relatively underdeveloped concerning information society indicators. The settlements of Tolna County have an advantage both in comparison to the other two counties in the region and to the national average in almost all aspects of information society. This fact can mostly be attributed to the relatively large average size of the settlements in Tolna. In general, the development of information society is increasing with the size of the settlements.

The introduced statistical indicators were used to create a new index, which can measure the existence and use of information infrastructure in Hungarian settlements. The index values have shown that the best performing settlements are in micro-regions without disadvantageous position and that they are more populated towns or located within their agglomeration. The less populated settlements in an underdeveloped microregion have a more disadvantageous position in information society. Therefore, the information readiness may create differences in a similar way to the economic development. It means that the central and most populated territories and their agglomeration have the best performance, and those settlements, which are far from the centre, are in a disadvantageous position regarding information readiness. Furthermore, as the index values represented, there may be a correlation between the economic development and information readiness of a settlement. Therefore, the next stage would be to expand the study to analyse the relationship between the information readiness and stage of economic development.

There are some limitations in the analysis, which mostly result from the accessibility of data. These are the first results of the index. Further research would include developing the index with new data. Indicators that measure the economic and social 
inequalities (like income or higher educated people) would also be involved to explain what could cause the measured territorial differences in the information society. The intention would be to expand the research to other parts of Hungary, in order to compare the different territories. However, from the work it can be assumed that the optimal level of a nationwide analysis is the micro-regional level; therefore, the intention would be to modify the database in further research.

\section{REFERENCES}

Annoni, P.-Kozovska, K. (2010): EU Regional Competitiveness Index 2010 JRC Scientific and Technical Reports, Luxembourg.

Bakonyi, P.-Bálint, L. (1996): Kutatási-felsőoktatási hálózatok: az információs társadalom elöfutárai InfoTársadalomtudomány 38: 31-45.

Döry, T.-Ponácz, Gy. M. (2003): Az infokommunikációs ágazatok szerepe és súlya a magyar városhálózatban Tér és Társadalom 17 (3): 165-181.

Erdősi, F. (2002): A kommunikáció általános földrajza In.: Tóth, J. (ed.): Általános Társadalomföldrajz II. pp. 83-142., Dialóg Campus kiadó, Budapest-Pécs.

Farkas, J. (2001): Az ipari társadalomtól az információs társadalomig Magyar Tudomány 48 (3): 271-282.

Farkas, J. (2002): Információs- vagy tudástársadalom Infonia szakkönyvek, Aula kiadó, Budapest.

Fodor, I. (2000): Merre megy a világ gazdasága, merre mehetünk mi? In.: Glatz, F. (ed.): Az információs társadalom pp. 95-112., Magyar Tudományos Akadémia, Budapest.

Graham, S. (2000): Bridging Urban Digital Divides? Urban polarization and Information and Communications Technologies (ICT): Current Trends and Policy Prospects Background paper for the United Nations Centre for Human Settlements (UNCHS), New York

ITU (2013): Measuring the information society International Telecommunication Union, Geneva.

Jakobi, Á. (2007): Hagyományos és új területi különbségek az információs társadalomban Doktori értekezés. ELTE TTK Földtudományi Doktori Iskola, Budapest.

Jakobi, Á. (2014): Újszerü területi statisztikai adatgyüjtési lehetőségek az információs világ egyenlötlenségeinek kutatásában Területi Statisztika 54 (1): 35-52.

Jakobi, Á.-Lengyel, B. (2014): Egy online közösségi háló offline földrajza, avagy a távolság és a méret szerepének magyar empíriái Tér és Társadalom 28 (1): pp. 40-61.

Lengyel, I.-Rechnitzer, J. (2000) A városok versenyképességéről In: Horváth, Gy.-Rechnitzer, J. (eds.): Magyarország területi szerkezete és folyamatai az ezredfordulón pp. 130-152., MTA RKK, Pécs.

Lengyel, I. (2010): Regionális gazdaságfejlesztés Akadémiai Kiadó, Budapest.

Masuda, Y. (1980): The Information Society as Post-Industrial Society World Future Society, Bethesda.

van der Meer, A.-van Winden, W.-Woets, P. (2003): ICT clusters in European cities during the 1990s: development patterns and policy Lessons Paper for the $43^{\text {rd }}$ European Congress of the Regional Science Association $27^{\text {th }}-30^{\text {th }}$ August 2003, Jyväskylä, Finland.

https://www.jyu.fi/ersa2003/cdrom/papers/73.pdf [downloaded: $6^{\text {th }}$ November 2014]

Nagy, G. - Kanalas, I. (eds.) (2003): Régiók az információs társadalomban MTA RKK Alföldi Tudományos Intézete, Kecskemét.

OECD (1996): The Knowledge-Based Economy OECD Publications, Párizs.

Rechnitzer, J. (1990): A számítástechnika területi terjedése Magyarországon Ts -2/2 Program Iroda, BudapestGyör.

Rechnitzer, J. (1993): Szétszakadás vagy felzárkózás? A térszerkezetet alakító innovációk MTA RKK, Győr.

Rechnitzer, J.-Grosz, A.-Csizmadia, Z. (2003): A magyar városhálózat tagozódása az infokommunikációs infrastruktúra alapján az ezredfordulón Tér és Társadalom 17 (3): 145-163.

Ropolyi, L. (2006): Információ, tudás, társadalom Magyar Tudomány 54 (1): 15-21.

Szépvölgyi, Á. (2008): Az információs társadalom térszerkezet alakító hatásai Studia Geographica. 20., Debreceni Egyetem, Debrecen.

Szerb, L.-Acs, Z.J.-Autio, E.-Ortega-Argilés, R.-Komlósi, É. (2014): REDI: The Regional Entrepreneurship and Development Index - Measuring regional entrepreneurship Report for the European 
Commission Directorate-General Regional and Urban Policy under contract number NO 2012.CE.16.BAT.057.

Vajkai, A. (2008): Az információs társadalom területi és módszertani vizsgálata E-Government tanulmányok XXI. E-Government Alapítvány a Közigazgatás Modernizációjáért, Budapest.

Webster, F. (1995): Theories of the Information Society Routledge, London-New York.

Z. Karvalics, L. (2005): Információ, tudás, társadalom, gazdaság, technológia: egy egységes terminológia felé Információs társadalom 5 (4): 7-17.

\section{Appendices}

\section{Transformation of the indicators}

Appendix 1

\begin{tabular}{|c|c|}
\hline Year & Transformed indicators and main indicators (skewness values were higher than 1) \\
\hline 2005 & Micro-regional main indicator (after multiplying the original indicators) \\
\hline 2006 & $\begin{array}{l}\text { Number of PCs per } 1000 \text { capita and micro-regional main indicator, } \\
\text { which was created from two original indicators and transformed PC indicator }\end{array}$ \\
\hline 2007 & $\begin{array}{l}\text { Number of mobile phone subscriptions per } 1000 \text { capita and number of PCs } \\
\text { per } 1000 \text { capita }\end{array}$ \\
\hline 2008 & $\begin{array}{l}\text { Number of PCs per } 1000 \text { capita and micro-regional main indicator, } \\
\text { which was created from two original indicators and transformed PC indicator }\end{array}$ \\
\hline 2009 & $\begin{array}{l}\text { Number of PCs per } 1000 \text { capita and micro-regional indicator, } \\
\text { which was created from two original indicators and transformed PC indicator }\end{array}$ \\
\hline 2010 & $\begin{array}{l}\text { Number of mobile phone subscriptions per } 1000 \text { capita and number of PCs } \\
\text { per } 1000 \text { capita }\end{array}$ \\
\hline 2011 & $\begin{array}{l}\text { Number of mobile phone subscriptions per } 1000 \text { capita and number of PCs } \\
\text { per } 1000 \text { capita }\end{array}$ \\
\hline 2012 & $\begin{array}{l}\text { Number of mobile phone subscriptions per } 1000 \text { capita and number of PCs } \\
\text { per } 1000 \text { capita }\end{array}$ \\
\hline
\end{tabular}

Spearman's rank correlation coefficient values

\begin{tabular}{l|c|c|c|c|c|c|c|c}
\hline & 2005 & 2006 & 2007 & 2008 & 2009 & 2010 & 2011 & 2012 \\
\hline $\begin{array}{c}\text { First sensitivity } \\
\text { test }\end{array}$ & 0.926 & 0.960 & 0.967 & 0.955 & 0.949 & 0.952 & 0.954 & 0.954 \\
$\begin{array}{c}\text { Second sensitivity } \\
\text { test }\end{array}$ & 0.863 & 0.896 & 0.963 & 0.896 & 0.897 & 0.955 & 0.895 & 0.851 \\
$\begin{array}{c}\text { Eliminated main } \\
\text { indicator in } \\
\text { the second test }\end{array}$ & $\begin{array}{c}\text { micro- } \\
\text { regional } \\
\text { indicator }\end{array}$ & $\begin{array}{c}\text { cable TV } \\
\text { sub- } \\
\text { scription }\end{array}$ & $\begin{array}{c}\text { phone } \\
\text { lines }\end{array}$ & $\begin{array}{c}\text { internet } \\
\text { sub- } \\
\text { scription }\end{array}$ & $\begin{array}{c}\text { micro- } \\
\text { regional } \\
\text { indicator }\end{array}$ & $\begin{array}{c}\text { phone } \\
\text { lines }\end{array}$ & $\begin{array}{c}\text { internet } \\
\text { sub- } \\
\text { scription }\end{array}$ & $\begin{array}{c}\text { cable tv } \\
\text { sub- } \\
\text { scription }\end{array}$
\end{tabular}

Notes: First sensitivity test refers to the examination comparing the values of normal and weighted average calculations. Second sensitivity test is the analysis when we eliminated a main indicator and calculated the index value without this main indicator. 